\title{
RUMINATION TIME MONITORING AS A POSSIBLE TOOL TO IMPROVE DIAGNOSTICS OF HEAT AND PARTURITION
}

\author{
Renáta Toušová ${ }^{1}$, Jaromír Ducháček ${ }^{1}$, Radim Codl $^{1}$, Jan Pytlík¹, Martin Ptáček ${ }^{1}$, \\ Matúš Gašparík ${ }^{1}$, Luděk Stádník ${ }^{1}$ \\ ${ }^{1}$ Department of Animal Science, Faculty of Agrobiology, Food and Natural Resources, Czech University of Life \\ Sciences Prague, Kamýcká 129, 165 00, Prague 6 - Suchdol, Czech Republic
}

Link to this article: https://doi.org/10.11118/actaun202068010109

Received: 22. 10. 2019, Accepted: 5. 12. 2019

To cite this article: TOUŠOVÁ RENÁTA, DUCHÁČEK JAROMÍR, CODL RADIM, PYTLÍK JAN, PTÁČEK MARTIN, GAŠPARÍK MATÚŠ, STÁDNÍK LUDĚK. 2020. Rumination Time Monitoring as a Possible Tool to Improve Diagnostics of Heat and Parturition. Acta Universitatis Agriculturae et Silviculturae Mendelianae Brunensis, 68(1): 109-117.

\begin{abstract}
Rumination time is one of possible parameters for observing not only feed management and health status, but also some reproductive characteristics such as heat or periparturient period. The evaluation of rumination time in this study was done on Holstein dairy cows in period around heat $(n=297)$ and around parturition ( $\mathrm{n}=322$ ) during one year. SAS 9.3 was used for statistic evaluation. Factors such as heat or periparturient period but also a parity or month within the year have significant impact on rumination time. The decrease of rumination time in the average of 19\% (more than 100 minutes) was observed in heat time against days before heat. Similarly, decrease of rumination time more than 110 minutes was observed on the day of parturition in comparison with days before that day. However, the return to normal rumination time values was gradual within 3 day after calving. The results indicated that in healthy cows the rumination time can be a good indicator not only of approaching periparturient but also of incoming heat.
\end{abstract}

Keywords: milk cattle, reproduction, rumination, calving, heat time, monitoring

\section{INTRODUCTION}

In dairy farming optimal breeding conditions with regard to feeding, microclimate, housing and other aspects are very important (Sordillo, 2016; Berry et al., 2016). Adequate milk production of outstanding quality parameters and preservation of good reproduction at the same time can be achieved only by optimization of animal living conditions. Whatever inconsistency between animals and environmental factors leads to stress situation with a consequence of metabolic problems, different diseases (Lacasse et al., 2018), decrease of milk yield and reproduction problems (Khan et al., 2016). It is exactly improved reproduction that is one of the main targets of the high-yield dairy farms in recent time. For this reason, modern farms apply different kind of strategies to improve reproduction and different automatic elements - such as leg or neck sensors - helping them to monitor cows during the whole day.

These simple neck or leg sensors equipped with passive chips are able to monitor various data related to locomotion activity or different physiological parameters. One of the possible applications is utilization of frequency of cows' ruminant activity during the day. Monitoring of rumination time allows detect metabolic disorders, heat time, or reproduction problems and changes in health.

Rumination time is affected by quantity and quality of the feed ration, the parity and its phase (Beauchemin and Rode, 1997; Yang and 
Beauchemin, 2006; Adin et al., 2009). Bulky feed with higher fiber content requires higher amount of chewing movements (Suzuki et al., 2014). This can be put into context with length of individual feed particles, when longer particles require longer rumination time (Nørgaard et al., 2011). Another factor that affects the length of rumination is lying time (Schirmann et al., 2012) and heat time (Reith and Hoy, 2012; Mičiaková et al., 2018). According to de Ondarza et al. (2017) changes in rumination time may indicate health problem earlier than clinical changes occur and before decrease of milk production. Optimal rumination time in cattle should be in range of 8 to 10 hours, eventually 12 hour a day in 4 to 20 time intervals that last from 10 to 60 minutes (Gáspárdy et al., 2014; Liboreiro et al., 2015). Decrease of rumination time from the average by 30-40 minutes already represents some sort of problem. Reduction of rumination time can indicate some problem in metabolic activity, health status and fertility (Werner et al., 2018). Shortening of ruminant and lying time is confirmed indicator of approaching periparturient (Borchers et al., 2017). From the above-mentioned literary sources, it follows that the time of rumination is dependent on several factors and it is influenced partly by the health condition, partly the manifestations of heat or by periparturient and its difficulty. However, each study using different instruments to measure rumination time under different conditions and confirms different effects of heat and periparturient on this activity. The aim of this work was to evaluate the development of rumination time in dairy cows during the heat and during the periparturient period.

\section{MATERIALS AND METHODS}

\section{Breeding Management}

The experiment was carried out on a farm with Holstein breed in Pilsen region Czech Republic. At time of the study there was a total number of 636 dairy cows with average milk yield of $10494 \mathrm{~kg}, 3.87 \%$ fat and 3.43\% protein (standard 305 d lactation). In the study of the length of the rumination time based on selected indicators the total number of 550 cows were included. System Heatime with responder HR LD (herd rumination long distance) (SCR Engineers Ltd., SCR Europe, Italy) was used for identification of reproduction parameters (periparturient, heat). The observation was based on monitoring of chewing activity that was recorded by an acoustic rumination sensor placed on the collar, behind the left ear of the cow. Housing capacity of free stall barn with cubicles was 636 places. The boxes were stabled with manure separate using telescopic handler and beds were limed twice a week. Manure cleanup was carried out three times a day using a tractor with front plow. Cows were served with a complete feeding ration delivered by fodder mixing wagon Strautmann VertiMix 1700 Double (B. Strautmann \& Söhne GmbH u. Co. KG, Germany) with two screw conveyors, see Tab. I. Three feeding rations were used based on milk yield and respective phase of lactation. First feed ration was designed for cows and primiparous cows (first calf heifers) in their first part of lactation (6.-100. day of lactation). This ration was served once a day. Production feeding rate was served from 100 day till the end lactation two times a day. The last feed ration was designed for cows in their dry period and before periparturient and was delivered twice a day. Changes between dry period

I: The composition of feed ration for individual cattle groups

\begin{tabular}{lccc}
\hline \multicolumn{1}{c}{ Kind of component } & First part of lactation $(\mathrm{kg})$ & Production time $(\mathrm{kg})$ & Dry period $(\mathrm{kg})$ \\
\hline Corn silage & 18.00 & 22.00 & 8.00 \\
Production mix & 8.50 & 10.00 & - \\
Haylage - clover & 4.00 & 5.00 & 3.00 \\
Haylage - grass & 4.00 & 6.00 & 3.00 \\
Haylage - mixture & 3.50 & 5.00 & 5.00 \\
Meadow hay & 0.50 & 0.50 & 2.00 \\
Wheat straw & 0.50 & 0.40 & 3.00 \\
Brewer's grains & 5.00 & 6.00 & 6.00 \\
Beet molasses & 1.00 & 1.00 & - \\
Glycerol & 0.30 & - & - \\
Extruded corn + urea & 1.00 & 1.00 & 0.20 \\
Sodium bicarbonate & 0.15 & 0.15 & - \\
Periparturient pen - mix & - & - & 2.20 \\
\hline Total (kg) & 46.45 & 57.05 & 32.40 \\
\hline
\end{tabular}


feeding ration and start of lactation ration were gradual and started 14 days before parturition. The feed was push to a fodder table with tractor equipped with front plow in all stables nine times a day. Milking was carried out in herringbone parlour Germania (Germania Dairy Automation, Inc., USA) with fast output and $2 \times 12$ boxes. Cows were milked three times a day (at 2:00; at 10:50 and at 18:20). Reproduction management was secured by co. Insemina Horšovský Týn via artificial insemination procedures.

\section{Statistical Evaluation}

Statistical evaluation was carried out in SAS 9.3 (SAS/STAT® 9.3, 2011) program. The rumination time around the period of heat as the first parameter in the study was evaluated in the course of one year. Each tested cow was evaluated for 8 days, therefore the number of observations was 8 time higher than number of animals in test ( $n=2376$ ). The second parameter in study was the rumination time in periparturient period. Each tested cow was evaluated for 11 days, therefore the number of observations was 11 time higher than number of animals in test $(n=3220)$. Procedures MEANS and UNIVARIATE were used for dataset basic parameters determination. Pearson correlation coefficients computed by CORR procedure were used for analysis of mutual relationships. Procedure REG, method STEPWISE was used for choosing best model evaluation for observed parameters. Effect of parity was adapted on 5 levels (1. lactation, 2. lactation, 3. lactation, 4. lactation and 5 and other lactation) because the higher then 6 lactation had low frequency. Procedure GLM was used for evaluation of individual effect. Detailed evaluation of differences between effect levels were done with Tukey-Kramer test.

Model equations for rumination time around heat evaluation:

$y_{i j k l m}=\mu+a_{i}+b_{j}+c_{k}+d_{l}+b^{*}(D I M)+e_{i j k l m}$

when:

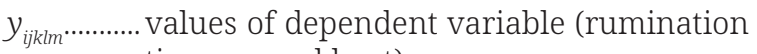
time around heat),

$\mu$................ general dependent variable;

$a_{i} \ldots \ldots . . . . . . .$. fixed effect of parity $(\mathrm{i}=1, \mathrm{n}=880 ; \mathrm{i}=2$, $\mathrm{n}=864 ; \mathrm{i}=3, \mathrm{n}=344 ; \mathrm{i}=4, \mathrm{n}=152$; $\mathrm{i}=5$ and other, $\mathrm{n}=136$ );

$b_{j}$............... fixed effect day of period around heat ( $j=7$ day before, $n=297 ; j=6$ day before, $n=297 ; j=5$ day before, $n=297 ; j=4$ day before, $n=297$; $j=3$ day before, $n=297$; $\mathrm{j}=2$ day before, $n=297 ; \mathrm{j}=1$ day before, $n=297 ; j$ = day of heat, $n=297$ );

$c_{k}$ …......... fixed effect month of heat $(\mathrm{k}=1, \mathrm{n}=8$; $\mathrm{k}=3, \mathrm{n}=88 ; \mathrm{k}=4, \mathrm{n}=152 ; \mathrm{k}=5, \mathrm{n}=208$; $\mathrm{k}=6, \mathrm{n}=192 ; \mathrm{k}=7, \mathrm{n}=232 ; \mathrm{k}=8, \mathrm{n}=160$; $\mathrm{k}=9, \mathrm{n}=288 ; \mathrm{k}=10, \mathrm{n}=384 ; \mathrm{k}=11, \mathrm{n}=336$; $\mathrm{k}=12, \mathrm{n}=328$ ); $d_{l}$.............. fixed repeated effect of animal ( $\left.\mathrm{n}=297\right)$;

$b^{*}(D I M)$... linear regression on lactation day in heat;

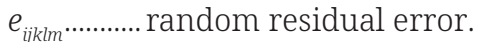

Model equation for rumination in periparturient period:

$y_{i j k l m}=\mu+a_{i}+b_{j}+c_{k}+d_{l}+b^{*}(L C)+e_{i j k l m}$

when:

$y_{i j k l m}$........... values of dependent variable (rumination time in periparturient period),

$\mu$................ general dependent variable;

$a_{i} \ldots \ldots . . . . . . . .$. fixed effect of parity $(\mathrm{i}=2, \mathrm{n}=1815 ; \mathrm{i}=3$, $\mathrm{n}=924 ; \mathrm{i}=4, \mathrm{n}=484 ; \mathrm{i}=5$ and other, $n=319)$;

$b_{j}$................ fixed effect day of periparturient period ( $\mathrm{j}=7$ day before, $\mathrm{n}=322 ; \mathrm{j}=6$ day before, $n=322 ; j=5$ day before, $n=322 ; j=4$ day before, $n=322 ; j=3$ day before, $n=322$; $\mathrm{j}=2$ day before, $\mathrm{n}=322 ; \mathrm{j}=1$ day before, $n=322 ; j=$ calving day, $n=322 ; j=1$ day after, $n=322 ; j=2$ day after, $n=322$; $\mathrm{j}=3$ day after, $\mathrm{n}=322$ );

$c_{k}$ …......... fixed effect month of calving $(\mathrm{k}=1$, $\mathrm{n}=231 ; \mathrm{k}=2, \mathrm{n}=253 ; \mathrm{k}=3, \mathrm{n}=231 ; \mathrm{k}=4$, $\mathrm{n}=132 ; \mathrm{k}=5, \mathrm{n}=297 ; \mathrm{k}=6, \mathrm{n}=209 ; \mathrm{k}=7$, $\mathrm{n}=374 ; \mathrm{k}=8, \mathrm{n}=418 ; \mathrm{k}=9, \mathrm{n}=330 ; \mathrm{k}=10$, $\mathrm{n}=363 ; \mathrm{k}=11, \mathrm{n}=341 ; \mathrm{k}=12, \mathrm{n}=363)$;

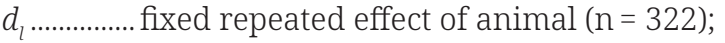

$b^{*}(L C)$...... linear regression on length of calving;

$e_{i j k l m}$........... random residual error.

The significance levels $\mathrm{P}<0.05, \mathrm{P}<0.01$ and $\mathrm{P}<0.001$ were used to evaluate differences between groups.

\section{RESULTS}

First part of evaluated data deals with basic data statistic of heat and parturition. Rumination time in period from 7 to 2 days before heat was without any changes with average of 625 minutes $(n=297)$. Minimal values in this period were in the range from 359 to 492 minutes and maximal values in range from 795 to 830 minutes. Decrease of rumination activity has been recorded 1 day before heat (610.10 min) with reduction of ruminating activity by $2.5 \%$. On the day of heat the period of chewing was about $81 \%$ (508.69 min) in comparison with the period of 7 to 2 days before heat. This decrease of approximately 100 minutes was noticeable on minimal and maximal values. This difference is also reflected in standard deviations, which increases with the approaching heat.

Evaluation of rumination time in period before parturition was based on 322 observations. Average time of rumination in this period decreased only minimally - from 601.01 minutes (7 days before parturition) to 585.29 minutes (1 day before parturition). In this period standard deviations increased (from 73.59 to 89.07 minutes) with relatively small changes in minimum and maximum 
values. On the day of parturition the average rumination time decreased to 383.09 minutes (reduction of $36.26 \%$ compared to the time of chewing 7 days before delivery). In addition, there was a significant increase in the standard deviation indicating a different physiological state of individual dairy cows at delivery and differences in their response to the physiological stress of parturition. Subsequently, the rumination time returned slowly to normal after calving. On the first day after parturition only 389.66 minutes of rumination time were recorded on average and with relatively large individual differences between individual animals (from 3 to 630 minutes). On the second day after calving the rumination time has increased by 78.84 minutes on average. On the third day after calving the average rumination time of 532.36 minutes was measured. Standard deviations of the length of rumination time in first 3 days after calving and thus the differences between animals were quite high (SD values from 117,38 till 122,67 minutes).

In Tab. II are shown correlations between parity and length of rumination time measured from the seventh day before heat to the oestrus. The parity has low correlation to rumination time on heat day ( $\mathrm{r}=0.139$; $\mathrm{P}<0.05$ ). Rumination periods in days before heat were strongly correlated $(r=0.490$ to $0.668 ; \mathrm{P}<0.01)$. Periods of rumination 7 days before heat in comparison with the length of rumination period on the day of heat were in weaker correlation $(\mathrm{r}=0.367$ to $0.421 ; \mathrm{P}<0.01)$.
These results indicate not only the appropriateness of monitoring the time of rumination before heat, but also certain individuality between observed animals with respect to their metabolic state.

Tab. III shows relationships between parity and time of rumination in the course of 7 days before parturition, on the day of parturition and 3 days after calving. Parity was negatively correlated with all periods of rumination - before parturition, in time of parturition and in time after $(r=-0.254$ to -0.438; P < 0.01). Durations of rumination between seventh and the first day before parturition were very strongly correlated $(r=0.451$ to 0.665 ; $\mathrm{P}<0.01$ ). Duration of rumination time before parturition with time of ruminating in the day of parturition were in medium strong and strong correlation $(r=0.306$ to $0.445 ; \mathrm{P}<0.01$ ). Relatively large dispersion of correlation intension was detected between time of rumination in days before parturition and in days after parturition ( $r=0.198$ to 0.433 ; $\mathrm{P}<0.01$ ). In opposite, the rumination time in the day of parturition was in medium strong correlation only with rumination time in first day after parturition $(r=0.393 ; P<0.01)$. Time of rumination in the day of parturition and time of rumination in second and third day after calving was only in a weak correlation ( $r=0.123$ to $0.131 ; \mathrm{P}<0.05$ ). These results can indicate that cows deal differently based on physiological stress of parturition and postpartum period. Eventually, the correlation between time of rumination in postpartum were high again ( $\mathrm{r}=0.425$ to $0.607 ; \mathrm{P}<0.01)$.

II: Correlations between rumination time and days before and in heat period

\begin{tabular}{|c|c|c|c|c|c|c|c|c|c|}
\hline & & $\begin{array}{c}7 \text { day } \\
\text { before }\end{array}$ & $\begin{array}{c}6 \text { day } \\
\text { before }\end{array}$ & $\begin{array}{c}5 \text { day } \\
\text { before }\end{array}$ & $\begin{array}{c}4 \text { day } \\
\text { before }\end{array}$ & $\begin{array}{c}3 \text { day } \\
\text { before }\end{array}$ & $\begin{array}{c}2 \text { day } \\
\text { before }\end{array}$ & $\begin{array}{c}1 \text { day } \\
\text { before }\end{array}$ & heat day \\
\hline \multirow{2}{*}{ parity } & $\mathrm{r}$ & 0.053 & 0.008 & -0.018 & -0.030 & 0.026 & -0.044 & 0.064 & 0.139 \\
\hline & $\mathrm{P}$ & 0.360 & 0.889 & 0.751 & 0.610 & 0.655 & 0.454 & 0.268 & 0.017 \\
\hline \multirow{2}{*}{$\begin{array}{l}7 \text { day } \\
\text { before }\end{array}$} & $\mathrm{r}$ & & 0.594 & 0.632 & 0.668 & 0.604 & 0.569 & 0.554 & 0.391 \\
\hline & $\mathrm{P}$ & & $<0.001$ & $<0.001$ & $<0.001$ & $<0.001$ & $<0.001$ & $<0.001$ & $<0.001$ \\
\hline \multirow{2}{*}{$\begin{array}{l}6 \text { day } \\
\text { before }\end{array}$} & $\mathrm{r}$ & & & 0.561 & 0.612 & 0.533 & 0.518 & 0.511 & 0.369 \\
\hline & $\mathrm{P}$ & & & $<0.001$ & $<0.001$ & $<0.001$ & $<0.001$ & $<0.001$ & $<0.001$ \\
\hline \multirow{2}{*}{$\begin{array}{l}5 \text { day } \\
\text { before }\end{array}$} & $\mathrm{r}$ & & & & 0.629 & 0.619 & 0.650 & 0.490 & 0.414 \\
\hline & $\mathrm{P}$ & & & & $<0.001$ & $<0.001$ & $<0.001$ & $<0.001$ & $<0.001$ \\
\hline \multirow{2}{*}{$\begin{array}{l}4 \text { day } \\
\text { before }\end{array}$} & $\mathrm{r}$ & & & & & 0.632 & 0.642 & 0.561 & 0.435 \\
\hline & $\mathrm{P}$ & & & & & $<0.001$ & $<0.001$ & $<0.001$ & $<0.001$ \\
\hline \multirow{2}{*}{$\begin{array}{l}3 \text { day } \\
\text { before }\end{array}$} & $\mathrm{r}$ & & & & & & 0.583 & 0.492 & 0.400 \\
\hline & $\mathrm{P}$ & & & & & & $<0.001$ & $<0.001$ & $<0.001$ \\
\hline \multirow{2}{*}{$\begin{array}{l}2 \text { day } \\
\text { before }\end{array}$} & $\mathrm{r}$ & & & & & & & 0.506 & 0.367 \\
\hline & $\mathrm{P}$ & & & & & & & $<0.001$ & $<0.001$ \\
\hline \multirow{2}{*}{$\begin{array}{l}1 \text { day } \\
\text { before }\end{array}$} & $\mathrm{r}$ & & & & & & & & 0.421 \\
\hline & $\mathrm{P}$ & & & & & & & & $<0.001$ \\
\hline
\end{tabular}

r ... correlation coefficient; P .... statistical significance 
III: Correlations between rumination time and days of periparturient period

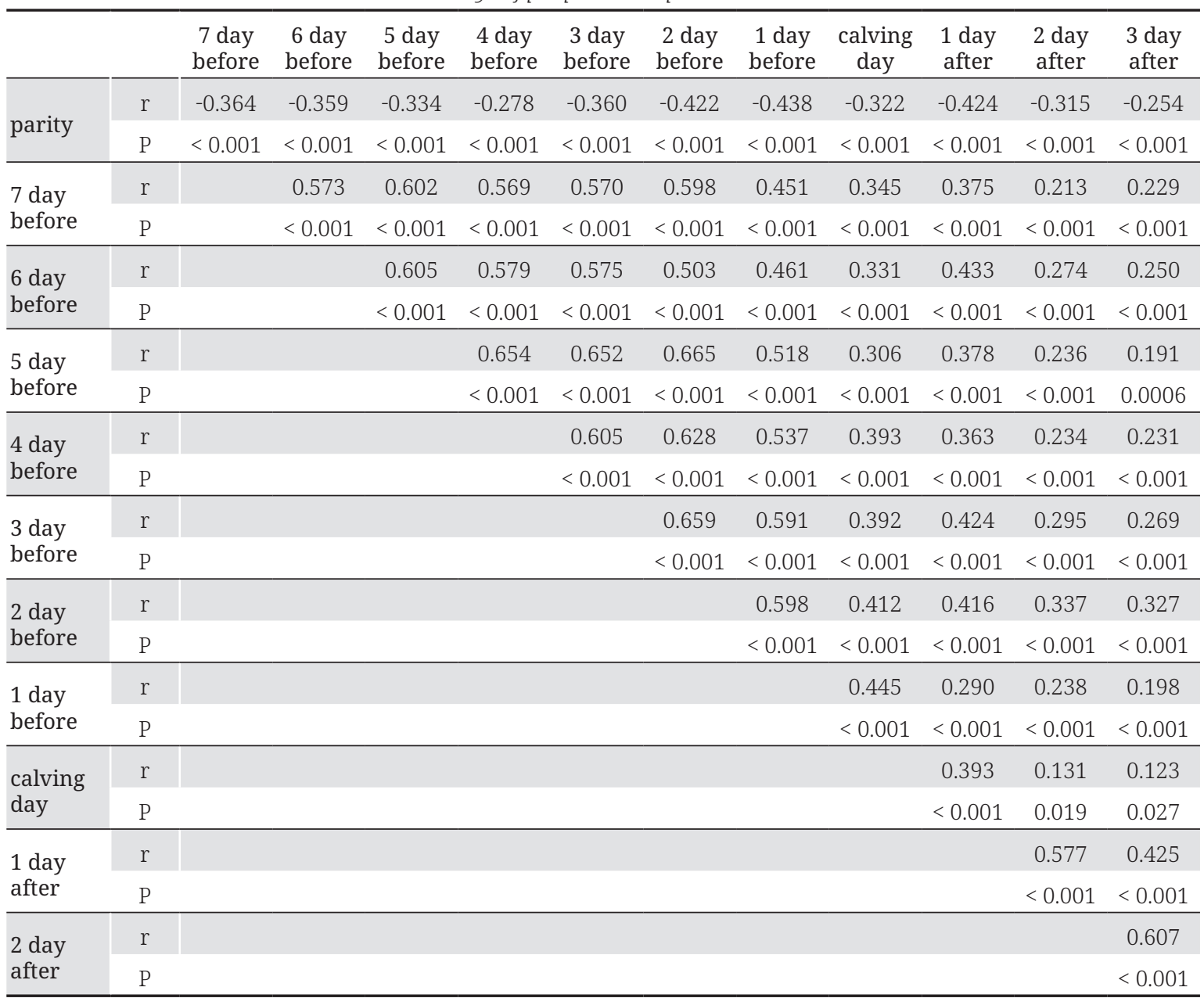

$\mathrm{r}$... correlation coefficient; $\mathrm{P}$.... statistical significance.

Detailed evaluation was made by the GLM procedure (ANOVA method). For evaluation of rumination time before the heat and during heat, effects of parity, month of heat, days of lactation and the period (days before the heat and the days of heat) were entered into model equation. All described effects were statistically significant $(\mathrm{P}<0.01)$. Model equation $(\mathrm{P}<0.01)$ in this evaluation explained $28.7 \%$ of the variance of ruminating time. Within the effect of parity, low values for animals calved for the first time and animals in fifth and more lactation were observed. In opposite, animals in second, third and fourth lactation had slightly higher and substantially more balanced length of rumination time. With increased parity the medium error and thus also differences among animals were increased Effect of month of heat exhibited many differences, which were statistically significant $(\mathrm{P}<0.05)$. The highest values were obtained in May and June and the lowest values were obtained from January to March. It is to a certain extent connected with quality of feed ration. Results of effect of period are shown in Fig. 1. It follows that between the seventh and second day before heat there are only minimal fluctuations in rumination time. Statistically significant decrease ( $\mathrm{P}<0.05)$ is noticeable on the day before detected heat. Significant decrease occurs in the day of heat $(\mathrm{P}<0.01)$. The decrease in comparison to the day before heat is 101.42 minutes in average. The decrease of $18.58 \%$ was recorded comparing the length of rumination in the day of heat and 7 days before the heat.

For evaluation of rumination time in the periparturient period till the day of parturition the following effects were recorded: parity, month of parturition, length of parturition and the period of 7 days before and 3 days after parturition. In this case all effects of model equation were significant $(\mathrm{P}<0.01)$. The model equation explained 50.9\% variability of ruminating time in parturition period. Due to the use of HR LD responders only at the first periparturient only differences among animals on the second, third, fourth, respectively fifth and more lactations were evaluated. It was evident, that rumination time has decreased significantly $(\mathrm{P}<0.05)$ with increased age of animals and with increased parity. Difference between dairy cows 


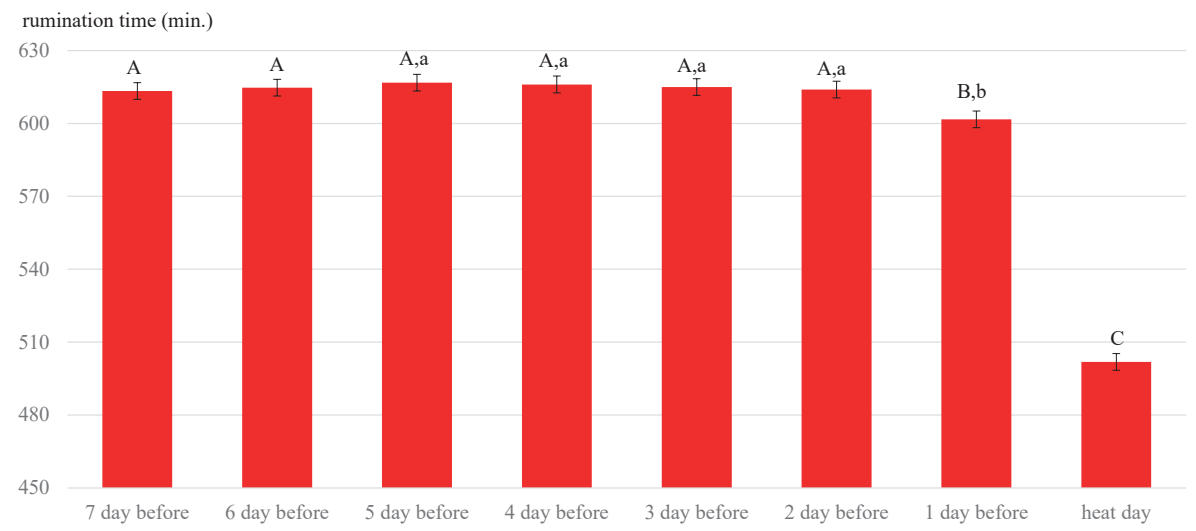

1: Evaluation rumination time in period before and in heat

Different letters (A, B, C; resp. a, b) in columns means statistical significance $\mathrm{P}<0.01$ (resp. $\mathrm{P}<0.05$ )

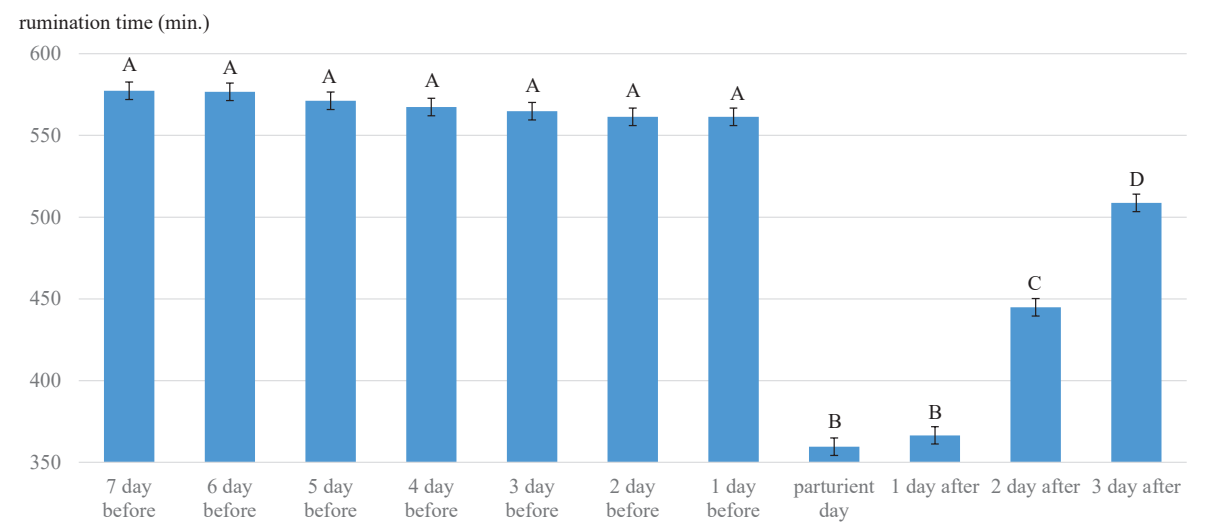

2: Evaluation of rumination time in period around periparturient

Different letters in columns means statistical significance $\mathrm{P}<0.01$

on the second lactation and cows on the fifth and more lactation was actually 96.93 minutes. Within the effect of month of parturition as well as in the evaluation of the month of heat many significant differences $(\mathrm{P}<0.05)$ were recorded. The longest rumination times were recorded during May, June and in October. On the other hand, the lowest values were found from January till March and also during September. These results confirmed relationship to feed ration quality during the year. In Fig. 2, the evaluation of length of rumination time in parturition period (from 7 days before to 3 days after parturition) is presented. From the seventh day before parturition to one day before parturition the rumination time has slightly decreasing tendency. Nevertheless, the decrease is not statistically conclusive. On the other hand the difference of the length of rumination time recorded one day before parturition and on the day of the parturition was 201.74 minutes. Total decrease of rumination time during the period from 7 days before parturition till the day of parturition was $37.71 \%$. Which means that in all evaluated days before parturition time of feeding and ruminating were significantly longer $(\mathrm{P}<0.01)$. One day after parturition the rumination time has slightly increased
(+6.94 minutes) nevertheless, it was significantly lower $(\mathrm{P}<0.01)$ than in all evaluated days before parturition. On the second day after parturition time of rumination was by 90 minutes longer than on the day of parturition. On the third day after parturition rumination time was over 500 minutes on average. On one side, the rumination time during the second and third day after parturition was significantly lower ( $P<0.01$ ), than one day before parturition and on the other hand it was significantly higher $(\mathrm{P}<0.01)$ than during parturition day.

\section{DISCUSSION}

Monitoring of the rumination time in relation to heat detection is subject of a number of studies, such as Pahl et al. (2015). These authors observed a decrease of rumination time in the period before heat till the onset of heat by 75 minutes, while we observed a decrease of more than 100 minutes. Similar results as in our study were observed by Reith and Hoy (2012), who recorded a decrease of 16 minutes between the second and first day before the heat and a decrease in rumination activity between the first day before the heat and day in heat by 67 minutes. 
Similarly, as in our results, the decrease of rumination time in the week before parturition was confirmed by Büchel and Sundrum (2014). Also results of Vacek and Krpálková (2017) indicate a decline in rumination activity, but only from the fifth day before calving. Similar values of rumination time, like in our study, are presented as daily physiological limit in a week before parturition by Liboreiro et al. (2015). In this study the average rumination time observed during the week before parturition was about 12 hours per day.

In detailed comparison of changes in rumination time from last two days before to the day of parturition similar results $(33 \%$ decrease in rumination time in the last two days before periparturient) were reported by Clark et al. (2015). A slightly higher decrease in rumination time (by 43$44 \%$ depending on the parity) in comparison with our observation were reported by Soriani et al. (2012) in their study. However, some studies, like Calamari et al. (2014), reported a significantly higher decrease of up to $70 \%$. A significant decrease of rumination activity in the day of parturition confirmed in their work also Pahl et al. (2015) and Vacek and Krpálková (2017). The latter authors report 245 minutes of rumination in the day of parturition, which is in average of more than one hour lower than that was found in our study. Similarly, Bar and Solomon (2010) reported a significant decrease in rumination time at birth, up to 255 minutes.

However, despite the relatively large increase of rumination time on the second day after parturition observed in our study, the results of Schirmann et al. (2013) who reported a return of the length of rumination time to the status before parturition within 48 hours cannot be fully confirmed.

In the context of the correlation analysis, numerous conclusive relationships were demonstrated not only between the length of rumination time in different days around the heat and calving, but also between the parity and time of the rumination. Positive relationship between the parity and rumination time during the heat corresponds with findings in the study of Pahl et al. (2015). In relation to the parity and the time of rumination on the day of calving, opposite trend was observed. This may be related to the age of animals and may indicate some changes in animal metabolism due to increasing parity and thus reduced ability to cope with the emerging negative energy balance at the beginning of lactation (Thorup et al., 2018).

As described above, in the detailed evaluation of the length of rumination time during the period around the heat more effects have been taken into account. In the case of primiparous cows significantly shorter period of rumination was observed. The possible explanation of this findings may be that first-time heifers in comparison with cows on higher parity spend less time on rumination, but more time at trough (Pahl et al., 2015). This may be given in addition to the smaller body framework of the first-time heifers and, as in the case of old cows, to the different metabolic profiles affected mainly by their genome. The effect of the season on the duration of the ruminating period may be explained by the differences in feed rations and its quality, which is one of the key factors determining the time of feed intake and time of rumination (Yang and Beauchemin, 2006; Adin et al., 2009). The effect of the period (days before the heat) showed similar tendencies, such as those described in the work of Reith and Hoy (2012).

In the framework of the evaluation of rumination time during the period around calving using the GLM procedure, a reduction in the length of rumination with increased parity and the age of the animal was observed. This finding is completely opposite to the Soriani et al. (2012) study. As part of the evaluation of the month of calving, results are influenced largely not only by climatic conditions, but also by seasonal differences in the composition of feed rations and their quality (Nørgaard et al., 2011). The effect of the period was manifested by expected tendencies. This is, for example, in line with the results observed in the work of Büchel and Sundrum (2014), when these authors observed the largest decrease in feed intake roughly in the last 12 hours before calving.

\section{CONCLUSION}

Time of ruminating and feeding is affected by many effects, such as composition of feed ration, age, parity and metabolic issues. Physiological displays of heat and parturition have effect on rumination and feed consumption time and are typically manifested by their decrease. Physiological displays of heat and parturition typically cause decrease of rumination time and feed consumption time. This decrease is highly correlated to these physiological phenomenon and it also differs from other manifestations of metabolic dis balance of dairy cows. From our results is obvious, that ruminating time can be good indicator not only for coming parturition, but also approaching heat in case of animal health. However, it is necessary to consider the age of animal, respectively parity. Nevertheless, determination of the day of parturition or heat of dam is affected by many other effects which are much more important than its age or parity. 


\section{REFERENCES}

ADIN, G., SOLOMON, R., NIKBACHAT, M., ZENOU, A., YOSEF, E., BROSH, A., SHABTAY, A., MABJEESH, S. J., HALACHMI, I. and MIRON, J. 2009. Effect of feeding cows in early lactation with diets differing in roughageneutral detergent fiber content on intake behavior, rumination, and milk production. J. Dairy Sci., 92(7): 3364-3373.

BAR, D. and SOLOMON, R. 2010. Rumination collars: what can they tell us. In: Proceedings of the First North American Conference on Precision Dairy Management. Canada: Toronto, Ontario, 2-5 March. Toronto, pp. 214-215.

BEAUCHEMIN, K. A. and RODE, L. M. 1997. Minimum versus optimum concentrations of fiber in dairy cow diets based on barley silage and concentrates of barley or corn. J. Dairy Sci., 80(8): 16291639.

BERRY, D. P., FRIGGENS, N. C., LUCY, M. and ROCHE, J. R. 2016. Milk Production and Fertility in Cattle. Annu. Rev. Anim. Biosci, 4: 269-290.

BORCHERS, M. R., CHANG, Y. M., PROUDFOOT, K. L., WADSWORTH, B. A., STONE, A. E. and BEWLEY, J. M. 2017. Machine-learning-based periparturient prediction from acitivity, lying, and uminating behaviours in dairy cattle. J. Dairy Sci., 100(7): 5664-5674.

BÜCHEL, S. and SUNDRUM, A. 2014. Short communication: Decrease in rumination time as an indicator of the onset of periparturient. J. Dairy Sci., 97(5): 3120-3127.

CALAMARI, L., SORIANI, N., PANELLA, G., PETRERA, F., MINUTI, A. and TREVISI, E. 2014. Rumination time around calving: An early signal to detect cows at greater risk of disease. J. Dairy Sci., 97(6): 3635-3647.

CLARK, C. E. F., LYONS, N. A., MILLAPAN, L., TALUKDER, S., CRONIN, G. M., KERRISK, K. L. and GARCIA, S. C. 2015. Rumination and activity levels as predictors of periparturient for dairy cows. Animal, 9(4): 691-695.

DE ONDARZA, M. B., EMANUELE, S. M. and SNIFFEN, C. J. 2017. Effect of increased dietary sugar on dairy cow performance as influenced by diet nutrient components and level of milk production. The Professional Animal Scientist, 33(6): 700-707.

GÁSPÁRDY, A., EFRAT, G., BAJCSY, Á. and FEKETE, S. 2014. Electronic monitoring of rumination activity as an indicator of health status and production traits in high-yielding dairy cows. Acta Vet. Hung., 62(4): 452-462.

KHAN, I., QURESHI, M. S., AHMAD, S., AKHTAR, S. and KHAN, H. 2016. Effect of Lactation and Breed on Reproductive Cyclicity Under Various States of Oxidative Stress in Dairy Cattle Breeds. Pak. J. Zool., 48(5): 1431-1441.

LACASSE, P., VANACKER, N., OLLIER, S. and STER, C. 2018. Innovative dairy cow management to improve resistance to metabolic and infectious diseases during the transition period. Res.Vet. Sci., 116: 40-46.

LIBOREIRO, D. N., MACHADO, K. S., SILVA, P. R. B., MATURANA, M. M., NISHIMURA, T. K., BRANDĂO, A. P., ENDRES, M. I. and CHEBEL, R. C. 2015. Characterization of peripartum rumination and aktivity of cows diagnosed with metabolic and uterine diseases. J. Dairy Sci., 98(10): 6812-6827.

MIČIAKOVÁ, M., STRAPÁK, P., SZENCZIOVÁ, I., STRAPÁKOVÁ, E. and HANUŠOVSKÝ, O. 2018. Several Methods of Estrus Detection in Cattle Dams: A Review. Acta Univ. Agric. Silvic. Mendelianae Brun., 66(2): 619-625.

NØRGAARD, P., NADEAU, E. and RANDBY, A. T. 2011. A new Nordic structure evaluation system for diets fed to dairy cows: a meta analysis. In: Modelling nutrient digestion and utilisation in farm animals. Wageningen: Wageningen Academic Publishers, pp. 112-120.

PAHL, C., HARTUNG, E., MAHLKOW-NERGE, K. and HAEUSSERMANN, A. 2015. Feeding characteristics and rumination time of dairy cows around estrus. J. Dairy Sci., 98(1): 148-154.

REITH, S. and HOY, S. 2012. Relationship between daily rumination time and estrus of dairy cows. J. Dairy Sci., 95(11): 6416-6420.

SAS, 2011. SAS/STAT®9.3 User's Guide. Cary, NC, USA: SAS Institute Inc.

SCHIRMANN, K., CHAPINAL, N., WEARY, D. M., HEUWIESER, W. and VON KEYSERLINGK, M. A. G. 2012. Rumination and its relationship to feeding and lying behavior in Holstein dairy cows. J. Dairy Sci., 95(6): 3212-3217.

SCHIRMANN, K., CHAPINAL, N., WEARY, D. M., VICKERS, L. and VON KEYSERLINGK, M. A. G. 2013. Rumination and feeding behavior before and after calving in dairy cows. J. Dairy Sci., 96(11): 70887092.

SORDILLO, L. M. 2016. Nutritional strategies to optimize dairy cattle immunity. J. Dairy Sci., 99(6): 4967-4982. 
SORIANI, N., TREVISI, E. and CALAMARI, L. 2012. Relationships between rumination time, metabolic conditions, and health status in dairy cows during the transition period. J. Anim. Sci., 90(12): 45444554.

SUZUKI, T., KAMIYA, Y., TANAKA, M., HATTORI, I., SAKAIGAICHI, T., TERAUCHI, T., NONAKA, I. and TERADA, F. 2014. Effect of fiber content of roughage on energy cost of rating and rumination in Holstein cows. Anim. Feed Sci. Tech., 196: 42-49.

THORUP, V. M., CHAGUNDA, M. G. G., FISCHER, A., WEISBJERG, M. R. and FRIGGENS, N. C. 2018. Robustness and sensitivity of a blueprint for on-farm estimation of dairy cow energy balance. J. Dairy Sci., 101(7): 6002-6018.

VACEK, M. and KRPÁLKOVÁ, L. 2017. Measurement of rumination time and its use in herd management [in Czech: Měření doby přežvykování a jeho využití při řízení stáda]. Náš chov, 77(10): 43-45.

WERNER, J., LESO, L., UMSTATTER, C., NIEDERHAUSER, J., KENNEDY, E., GEOGHEGAN, A., SHALLOO, L., SHICK, M. and O’BRIEN, B. 2018. Evaluation of the RumiWatchSystem for measuring grazing behavior of cows. J. Neurosci. Methods, 300: 138-146.

YANG, W. Z. and BEAUCHEMIN, K. A. 2006. Effects of physically effective fiber on chewing activity and ruminal pH of dairy cows fed diets based on barley silage. J. Dairy Sci., 89(1): 217-228.

Renáta Toušová: tousova@ af.czu.cz Jaromír Ducháček: duchacek@af.czu.cz Radim Codl: codl@af.czu.cz Jan Pytlík:pytlik@af.czu.cz Martin Ptáček: ptacekm@af.czu.cz Matúš Gašparík: gasparikm@af.czu.cz Luděk Stádník: stadnik@af.czu.cz 